\title{
PENGARUH AKTIVITAS BERLARI TERHADAP TEKANAN DARAH DAN SUHU PADA PRIA DEWASA NORMAL
}

\author{
${ }^{1}$ Go Handayani \\ ${ }^{2}$ Fransiska Lintong \\ ${ }^{3}$ Jimmy F. Rumampuk \\ ${ }^{\mathbf{1}}$ Kandidat Skripsi Fakultas Kedokteran Universitas Sam Ratulangi Manado
${ }^{2}$ Bagian Fisika Fakultas Kedokteran Universitas Sam Ratulangi Manado
Email: infinite0195@gmail.com
}

\begin{abstract}
Movement is a certain habit that never gone from every human being. A Person never stop to move even when he was asleep, because without realizing our heart is settled to pump out blood going to entire body. The quick heart beat can be feel on some situation for example; run, bike or heavy lifting. While run the heartbeat feel faster. Beside heartbeat, breathing and body temperature is also rise where breathing get deeper and faster resembling with body that feel hotter. The aim of this study is to see the influence of running activity toward blood pressure and body temperature. The research methodology used is cross sectional design. The research was conducted between September to November 2015. Subjects are 30 teenager attain the age of 18- 25 years old that selected through inclusion and exclusion criteria. Data analysis performed by Wilcoxon test using SPSS.The result showed that there are 24 people that has rise blood pressure and on the measuring body temperature there are 20 people has decrease of blood temperature after run. Conclusion: Research shows that there are significant contradiction of blood pressure before and after run. On the measure body temperature there are no significant contradiction before and after run.
\end{abstract}

Keywords: run, blood pressure, body temperature

\begin{abstract}
Abstrak: Gerak merupakan suatu kebiasaan yang tidak lepas dari setiap manusia. Manusia tidak pernah berhenti bergerak bahkan disaat seorang tidur, karena tanpa disadari jantung manusia tetap bergerak untuk memompa darah ke seluruh tubuh. Detak jantung yang kencang dapat kita rasakan pada keadaan-keadaan tertentu, contohnya; berlari, bersepeda atau mengangkat beban. Saat berlari, detak jantung terasa lebih kencang dan lebih cepat. Selain detak jantung, pernapasan dan suhu tubuh juga meningkat, dimana pernapasan lebih dalam dan cepat bersamaan dengan tubuh yang terasa panas. Tujuan dari penelitian ini adalah untuk melihat pengaruh berlari terhadap tekanan darah dan suhu. Metode penelitian yang digunakan adalah design potong lintang (cross sectional) yang dilaksanakan pada bulan September sampai November 2015. Subjek penelitian adalah 30 orang remaja yang berumur 18-25 tahun melalui kriteria inklusi dan eksklusi. Analisis data dilakukan uji statistik Wilcoxon dengan menggunakan SPSS. Hasil penelitian menunjukkan bahwa terdapat 24 orang yang mengalami peningkatan pada pengukuran tekanan darah dan pada pengukuran suhu ditemukan 20 orang yang mengalami penurunan suhu setelah berlari. Simpulan: Terdapat perbedaan yang signifikan pada pengukuran tekanan darah sebelum dan sesudah berlari. Pada pengukuran suhu, tidak terjadi perbedaan yang signifikan sebelum dan setelah berlari.
\end{abstract}

Kata kunci: berlari, tekanan darah, suhu

Gerak merupakan suatu kebiasaan yang tidak lepas dari setiap manusia. Manusia tidak pernah berhenti bergerak bahkan disaat seorang tidur, karena tanpa disadari 
jantung manusia tetap bergerak untuk memompa darah ke seluruh tubuh walaupun setiap orang memiliki aktivitas yang berbeda-beda setiap saat. Namun, seiring berkembangnya teknologi dari semua bidang yang ada, maka tingkat kesadaran akan aktivitas fisik yang sangat penting untuk kesehatan manusia sangat rendah. Sehingga banyak orang yang tidak mau berolahraga, padahal olahraga sangat berguna untuk kesehatan.

Dengan meningkatnya aktivitas fisik seseorang maka kebutuhan darah yang mengandung oksigen akan semakin besar. Kebutuhan ini akan dipenuhi oleh jantung dengan meningkatkan aliran darahnya. Hal ini juga direspon pembuluh darah dengan melebarkan diameter pembuluh darah (vasodilatasi) sehingga akan berdampak pada tekanan darah individu tersebut. ${ }^{1}$

Kecepatan didefinisikan sebagai perubahan posisi per satuan waktu. Dalam sistem MKS atau SI, satuan kecepatan adalah meter/detik atau m/s. ${ }^{2}$ Menurut Harsono (1988:261), mengemukakan bahwa : Kecepatan adalah kemampuan untuk melakukan gerakan yang sejenis secara berturut-turut dalam waktu yang sesingkat-singkatnya. Kecepatan dalam hal ini merupakan kecepatan bergerak untuk dapat melakukan pergerakan kaki yang cepat untuk mampu mengayunkan kaki bergerak ke depan dengan cepat. $^{3}$ Dan dapat disimpulkan bahwa kecepatan adalah kemampuan seseorang untuk melakukan suatu gerakan dalam waktu yang singkat. ${ }^{4}$

Suhu adalah besaran yang menyatakan derajat panas dingin suatu benda, semakin tinggi suhu suatu benda maka semakin panas benda tersebut dan semakin rendah suhu suatu benda maka semakin dingin benda tersebut. Suhu tubuh manusia sendiri merupakan perbedaan antara jumlah panas yang dproduksi oleh proses tubuh dan jumlah panas yang hilang ke lingkungan luar.

Manusia punya kemampuan untuk beradaptasi terhadap suhu lingkungan. Meningkatnya aktivitas fisik menyebabkan peningkatan suhu inti yang secara refleks memicu mekanisme pengeluaran panas. ${ }^{4}$

\section{METODE PENELITIAN}

Penelitian ini merupakan penelitian design potong lintang (cross sectional). Lokasi penelitian bertempatkan di Lapangan KONI Manado dengan luas panjang keliling 400 meter. Populasi penelitian adalah teman-teman mahasiswa yang sering beraktifitas di lapangan KONI. Kriteria dari subjek yaitu; pria yang sehat bugar dengan berat badan normal dan dalam rentang umur 18-25 tahun. Alat dan bahan yang digunakan adalah lembar Informed Consent penelitian, alat tulis menulis, laptop, sphygnomanometer, stetoskop, termometer dan stop watch.

Cara kerja dari penelitian ini adalah dengan meminta subjek berlari cepat mengitari jalur lari sebanyak 2 putaran dalam waktu lima menit, dan mencatat hasil pengukuran tekanan darah dan suhu yang terjadi sebelum dan setelah subjek berlari. Data yang terkumpul kemudian diolah dan disajikan dalam bentuk tabel.

\section{HASIL PENELITIAN}

Berdasarkan hasil penelitian yang dilakukan di Lapangan Koni Manado pada September sampai November 2015, maka diambil 30 subjek untuk penelitian ini. Dari 30 subjek ini masing - masing di ukur tekanan darah dan suhu sebelum dan sesudah berlari.

Tabel 1. menunjukkan umur dari 30 subjek yang diteliti. Responden paling banyak pada usia 20 tahun yaitu berjumlah 13 orang, dengan persentase 43,3\%. Dibandingkan dengan usia $<20$ dan $>20$.

Tabel 1. Umur Responden (Tahun)

\begin{tabular}{lll}
\hline & $\mathrm{n}$ & $\%$ \\
\hline $18-19$ & 2 & 6,6 \\
$20-22$ & 25 & 83,5 \\
$23-25$ & 3 & 9,9 \\
\hline Total & 30 & 100,0 \\
\hline
\end{tabular}

Tabel 2. menunjukkan status gizi dari subyek yang diteliti. Responden terbanyak adalah subjek yang memiliki index massa tubuh dalam status normal yaitu sebanyak 
25 orang, dan tidak ada subjek yang memiliki index massa tubuh yang masuk dalam kategori obesitas. Jumlah subjek yang memiliki berat badan lebih sebanyak dua orang tetapi status gizi berat badan lebih yang dimaksud tidak termasuk dalam kriteria obesitas.

Tabel 2. Distribusi Menurut Index Massa Tubuh

\begin{tabular}{lll}
\hline & $\mathrm{n}$ & $\%$ \\
\hline Normal & 25 & 83,3 \\
Overweight & 2 & 6,6 \\
Underweight & 3 & 10,0 \\
\hline Total & 30 & 100,0 \\
\hline
\end{tabular}

Tabel 3. menunjukkan data pengukuran tekanan darah sebelum dan sesudah berlari. Pada data, sebelum berlari tekanan darah sistole terendah adalah 100 mmHg dan yang tertinggi adalah 140 mmHg. Setelah berlari terjadi peningkatan pada tekanan darah sistole hingga mencapai $180 \mathrm{mmHg}$ dan dari data yang diambil terjadi penurunan pada sistole setelah berlari menjadi $90 \mathrm{mmHg}$.

Tabel 3. Data Hasil Pengukuran Tekanan Darah Sistolik Sebelum dan Sesudah Berlari

\begin{tabular}{lll}
\hline & TDS 1 & TDS 2 \\
\hline $\mathrm{N}$ & 30 & 30 \\
Minimum & 100 & 90 \\
Maximum & 140 & 180 \\
\hline
\end{tabular}

Tabel 4. Data Hasil Pengukuran Tekanan Darah Diastolik Sebelum dan Sesudah Berlari

\begin{tabular}{lll}
\hline & TDD 1 & TDD 2 \\
\hline $\mathrm{N}$ & 30 & 30 \\
Minimum & 60 & 50 \\
Maximum & 100 & 100 \\
\hline
\end{tabular}

Pada Tabel 4. Dapat dilihat bahwa sebelum berlari tekanan darah diastole terendah adalah $60 \mathrm{mmHg}$ dan yang tertinggi adalah $100 \mathrm{mmHg}$. Setelah berlari tekanan diastole terendah adalah $50 \mathrm{mmHg}$ dan yang tertinggi adalah $100 \mathrm{mmHg}$.

Tabel 5. menunjukkan efek berlari terhadap Tekanan darah dan suhu seorang pria dewasa normal. Pada Tekanan darah Sistole dimana nilai $\mathrm{P}=0,001<0,05$ sehingga dapat dinyatakan sesuai uji Wilcoxon dimana nilai $\alpha=0,05$, data tersebut dinyatakan terjadi perubahan yang signifikan antara Tekanan darah sistole sebelum berlari dan sesudah berlari.

Tabel 5. Data Hasil Uji Perbedaan Tekanan darah Sistole Sebelum dan Sesudah Berlari

\begin{tabular}{lll}
\hline TDS Sebelum & TDS Sesudah & Nilai p \\
\hline Menit 0 & Menit 5 & $\mathrm{P}=0,001$ \\
\hline
\end{tabular}

Tabel 6. Data Hasil Uji Perbedaan Tekanan darah Diastole Sebelum dan Sesudah Berlari

\begin{tabular}{lll}
\hline TDD Sebelum & TDD Sesudah & Nilai p \\
\hline Menit 0 & Menit 5 & $\mathrm{P}=0,002$ \\
\hline
\end{tabular}

Tabel di atas menunjukkan efek berlari terhadap Tekanan darah dan suhu seorang pria dewasa normal. Tekanan Sistole sebelum berlari dengan tekanan sistole setelah berlari. Pada Tekanan Darah Diastole dimana nilai $\mathrm{P}=0,002<0,05$ sehingga dapat dinyatakan terjadi perubahan yang signifikan antara Tekanan darah Diastole sebelum berlari dengan tekanan darah diastole setelah berlari.

Pada Tabel 7. hasil pengukuran Suhu dimana nilai $\mathrm{P}=0,608>0,05$ sehingga dapat dinyatakan bahwa tidak terdapat perubahan yang signifikan antara suhu sebelum dan sesudah berlari pada seoarang pria dewasa normal.

Tabel 7. Data Hasil Uji Perbedaan Tekanan darah Diastole Sebelum dan Sesudah Berlari

\begin{tabular}{lll}
\hline Suhu Sebelum & Suhu Sesudah & Nilai p \\
\hline Menit 0 & Menit 5 & $\mathrm{P}=0,608$
\end{tabular}

\section{BAHASAN}

Subjek dengan berat badan yang masuk kriteria obesitas tidak di gunakan, karena subjek yang memiliki status gizi obesitas akan mempegaruhi hasil pengukuran tekanan darah dan suhu setelah berlari. Karena orang yang obesitas 
memiliki suhu tubuh yang lebih rendah karena regulasi pada suhu akan lebih mudah berubah. Aktivitas fisik dari subjek dengan status gizi obesitas juga sangat berbeda dengan orang yang normal karena biasanya orang dengan status gizi obes tidak mampu berlari lama dan akan sangat berpengaruh pada pengambilan hasil tekanan darah.

\section{A. Tekanan Darah}

Dari penelitian yang dilakukan pada 30 orang subjek didapati hasil pengukuran tekanan darah sebelum dan sesudah belari. Pada hasil pengukuran tekanan darah di temukan 24 orang yang mempunyai tekanan darah yang meningkat. Tekanan darah yang meningkat ini dipengaruhi oleh tingkatan aktivitas. Tekanan darah setelah beraktivitas lebih besar dibandingkan dengan tekanan darah pada saat istirahat. Hal tersebut diakibatkan karena pada saat beraktivitas sel tubuh memerlukan pasokan O2 yang banyak akibat dari metabolisme sel yang bekerja semakin cepat pula dalam menghasilkan energi. Sehingga peredaran darah di dalam pembuluh darah akan semakin cepat dan curah darah yang dibutuhkan akan semakin besar. Akibat adanya vasodilatasi pada otot jantung dan otot rangka serta vasokontriksi arteriol yang menyebabkan arteriol menyempit dan kerja jantung tiap satuan waktupun bertambah sehingga volume darah pada arteriol akan meningkat dan tekanannyapun meningkat. Dapat dikatakan bahwa volume darah yang masuk dari arteri ke jantung meningkat. Pada organ-organ tersebut dan menyebabkan aliran darah ke saluran pencernaan dan ginjal berkurang. Persentase darah yang dialirkan ke organorgan tersebut untuk menunjang peningkatan aktivitas metabolik keduanya dan kerja jantung juga akan semakin cepat dalam memompa darah. ${ }^{5}$

Pada saat frekuensi denyut jantung cepat, tekanan arteri turun secara tajam selama fase ejeksi sistolik ventrikel karena katup atrioventrikulat tertarik kebawah meningkatkan kapasitas atrium. Kerja ini menyedot darah ke atrium dari vena besar.
Sedotan darah ke atrium selama sistolik turut membantu secara nyata pada arus balik vena. ${ }^{6}$ Hal ini menjelaskan mengapa pada beberapa sunjek terjadi penurunan pada tekanan sistole setelah berlari.

\section{B. Suhu}

Dari penelitian yang dilakukan pada 30 orang sampel didapati hasil pengukuran tekanan darah dan suhu sebelum dan sesudah berlari, subjek diminta berlari cepat memutari jalur lari selama tiga sampai lima menit atau sebanyak dua putaran. Pada hasil pengukuran suhu ditemukan 20 orang yang mengalami penurunan suhu setelah berlari.

Suhu tubuh dapat diartikan sebagai keseimbangan anatara panas yang diproduksi dengan panas yang hilang dari tubuh. Kulit merupakan organ tubuh yang bertanggung jawab untuk memelihara suhu tubuh agar tetap normal dengan mekanisme tertentu.

Panas diproduksi oleh tubuh melalui proses metabolisme, aktivitas otot dan sekresi kelenjar. Produksi panas dapat meningkat atau menurun dipengaruhi oleh suatu sebab, misalnya oleh karena penyakit ataupun stress. ${ }^{7}$

Panas dapat hilang dari tubuh melalui tiga cara, yatu; melalui kulit, dalam udara ekspirasi dan melalui urin dan feses. Panas yang hilang dari kulit melalui konduksi, radiasi, dan konveksi, melalui perspirasi dan penguapan keringat. Kehilangan ini dikontrol oleh variasi jumlah darah yang melewati kulit, dihasilkan oleh perubahan ukuran pembuluh darah didalamnya. Kehilangan panas melalui kulit dipengaruhi oleh jumlah dan jenis pakaian yang dikenakan. $^{8}$

Konduksi merupakan hilangnya panas secara langsung dari satu benda ke benda yang lebih dingin. Radiasi adalah penyebaran panas dari kulit ke udara yang lebih dingin. Konveksi bervariasi dengan aliran udara melalui kulit, misalnya ketika digerakkan oleh angin atau kipas angin. ${ }^{8}$

Penurunan suhu tubuh seseorang juga berhubungan dengan pacu jantung. Suhu 
tubuh berhubungan dengan detak jantung, dimana suhu tubuh mengalami naik turun sekitar $1^{0} \mathrm{C}$ per 24 jam. Temperatur tubuh manusia minimum selama tidur dan meningkat pada jam jam awal pagi. Mekanisme kontrol umpan balik negatif secaraaktif berjalan untuk memelihara temperatur titik dari kumpulan regulasi untuk suatu waktu pada hari tersebut. ${ }^{9}$ Keringat juga membantu proses penurunan suhu, akibat panas tubuh yang dihasilkan tubuh sudah terlalu tinggi maka panas tubuh dikeluarkan lewat keringat. Keringat disekresi akibat terjadinya dilatasi pembuluh darah kulit dibawah control sarag hipotalamus, korteks serebri dan bagian lain sistem saraf pusat.

\section{SIMPULAN}

1. Dari hasil Uji Wilcoxon, maka terjadi perubahan yang signifikan pada hasil pengukuran tekanan darah sebelum dan sesudah subjek berlari.

2. Dari hasil Uji Wilcoxon, maka tidak terjadi perubahan yang signifikan pada hasil pengukuran suhu sebelum dan sesudah berlari.

3. Terdapat pengaruh dari aktifitas fisik (berlari) terhadap tekanan darah dan suhu

4. Terdapat hubungan antara peningkatan tekanan darah dan penurunan suhu tubuh setelah berlari.

\section{SARAN}

Pada penelitian selanjutnya diharapkan subjek dapat berlari secara kontinyu dalam beberapa segmen untuk diukur tekanan darah dan suhu beberapa kali untuk dibandingkan apakah terdapat peningkatan jika subjek diminta untuk lari dalam beberapa segmen.

\section{DAFTAR PUSTAKA}

1. Rai Ade. T. Halim,. 2012. 101 Fitness di Usia 40+. Jakarta: Libri. p. 10

2. Agus F. C. TRAINING CENTER OLIMPIADE INTERNASIONAL. 2010 ; diunduh dari http://file.upi.edu/Direktori/FPMIPA/ JUR._PEND._FISIKA/19810812200 5011AGUS_FANY_CHANDRA_W/ Modul_I_Fisika_(Gerak)_IJSO_2010. pdf

3. Harsono. 1988. Coaching dan Aspek-aspek dalam Coaching, Depdikbud Dirjen Dikti. Jakarta : CV. Tambok Kusuma. p. 261

4. Lauralee Sherwood. Fisiologi Manusia Edisi 6 ; 2013.Jakarta : ECG. p. 717

5. R. Andrajati, E. Sukandar, J. Sigit, I Ketut, A. Adji, Kusnandar. 2008. Penuntun Praktikum Anatomi Fisiologi Manusia. Depok: Departemen Farmasi FMIPA UI.

6. Ganong, William F., MD., 2002. Buku Ajar Fisiologi Kedokteran. Edisi 20. Jakarta: EGC. p. 547-548

7. Asmadi. Teknik Prosedural Keperawatan : konsep dan aplikasi kebutuhan dasar klien : 2008. p. 155-158. Jakarta : salemba medika

8. john Girson. Fisiologi \& Anatomi Modern Untuk Perawat Edisi 2 ; 2003. Jakarta : ECG. p. 123 - 125, 236-240

9. Guyton, A.C. 1986. Text Book of Medical Physiology. W. B. Saunders Co. New York.

$\mathrm{H}$ : 889-890 